\title{
Morfometri Octopus vulgaris Cuvier, 1797 (Cephalopoda : Octopodidae) dari Perairan Popisi, Pulau Banggai Laut, Sulawesi Tengah
}

\author{
Inggrid Debora Hutagaol*, Sri Redjeki, Endang Sri Susilo \\ Departemen IImu Kelautan, Fakultas Perikanan dan Ilmu Kelautan, Universitas Diponegoro \\ JI. Prof. H. Soedarto S.H, Tembalang,Semarang, Jawa Tengah 50275 Indonesia \\ ${ }^{*}$ Corresponding author, e-mail: inggrid.debora@gmail.com
}

\begin{abstract}
ABSTRAK : Penting adanya informasi dasar tentang gurita dari perairan Indonesia untuk memperbesar pengelolahan dan pelestarian potensi laut Indonesia. Secara historis dibeberapa negara telah mengalami penurunan hasil tangkap gurita dalam beberapa tahun. Tujuan dari diadakannya penelitian ini adalah untuk melihat morfometri pada gurita vulgaris (Octopus vulgaris) dari Perairan Desa Popisi, Pulau Banggai Laut, Sulawesi Tengah dengan parameter panjang mantel, panjang lengan, berat, dan jenis kelamin. Sampel ditangkap oleh nelayan dengan alat pancing sederhana pada kedalaman 10-30 m dari perairan Banggai Laut. Gurita dibagi kedalam 4 kategori berdasarkan berat yang digunakan pengepul, yaitu kategori A, B, C, D. Gurita dari Desa Popisi pada bulan Maret 2018 dalam ukuran yang baik untuk di jual dan di ekspor, yaitu 87\% gurita hasil tangkapan berukuran besar dengan kategori A, B, dan C. Pulau Banggai Laut menjadi salah satu wilayah yang masih baik dalam penangkapan gurita karena penangkapan yang konservatif.
\end{abstract}

Kata kunci : Octopus vulgaris, Morfometri, Kelamin, Banggai Laut

\section{The Morphometry of Octopus vulgaris Cuvier, 1797 (Cephalopoda: Octopodidae) from the waters of Popisi, Banggai Laut Island, Central Sulawesi}

ABSTRACT : It is important to have basic information about octopus from Indonesian waters to enlarge the management and preservation of Indonesia's marine potential. Historically, in some countries, there has been a decline in octopus capture results in several years. The purpose of this study was to look at morphometry in octopus vulgaris (Octopus vulgaris) from the waters of Popisi Village, Banggai Laut Island, Central Sulawesi with parameters of mantle length, arm length, weight, and sex. The sample was captured by fishermen with a simple fishing rod at a depth of 10-30 m from the waters of Banggai Laut. Octopus is divided into 4 categories based on the weight used by collectors, namely categories $A, B, C, D$. Octopus from Popisi Village in March 2018 in a good size to sell and export, namely 87\% large-sized octopus with categories $A, B$, and $C$. Banggai Laut Island is one of the areas that is still good in capturing octopuses due to conservative arrests.

Keywords : Octopus vulgaris, Morphometry, Sex, Banggai Laut

\section{PENDAHULUAN}

Ekspor, menurut komoditas utama yaitu cumi-sotong-gurita, tahun 2012-2017 yang ditunjukkan oleh KKP Indonesia, mengalami peningkatan sebesar 21,41\% pertahun. Pulau Banggai Laut, Sulawesi Tengah merupakan salah satu wilayah Indonesia yang telah memanfaatkan laut untuk meningkatkan perekonomian daerah. Diantara berbagai spesies yang terhimpun dalam kelas Cephalopoda, gurita merupakan kelompok spesies yang sangat cerdas (Nande et al., 2017; McConnell, 2010), dan hidup hampir di seluruh lautan yakni dari laut tropis sampai ke kutub utara dan kutub selatan (Hoving dan Haddock, 2017). Selain O. vulgaris, Sulawesi Tengah juga diketahui sebagai habitat paper nautilus yang sangat jarang dikaji (Sarif et al., 2018).

Data tangkapan gurita di dunia masih gagal dalam mencatat gurita hasil tangkapan sederhana (subsistence and artisanal harvests) dan hanya mengandalkan data ekspor. Akibatnya, data morfologi gurita dianggap sangat kasar dan diragukan. Pada beberapa negara telah terjadi penurunan penjualan seperti di Republik Korea dan Republik Rakyat Demokratik Korea, Federasi 
Rusia dan dua negara Amerika Tengah, Honduras dan St. Vincent, tercatat mengekspor 112,461 ton dan 137,722 ton pada tahun 1991, namun tahun 2010 hanya sekitar 49,259 ton saja (FAO, 2016). Octopus vulgaris di negara Mauritania juga telah mengalami penurunan dari 70.000 ton menjadi 15.000 ton antara tahun 1982 dan tahun 2006.

Ukuran tangkapan yang kecil dan penurunan hasil tangkap akibat overexploited menjadi pertimbangan untuk mengetahui ukuran yang baik dalam penangkapan gurita, disamping dapat meningkatkan nilai ekspor dan menjaga kelestariaannya. Mengetahui morfometri pada gurita vulgaris di Perairan Desa Popisi, Pulau Banggai Laut, Sulawesi Tengah, menjadi langkah awal untuk melengkapi informasi tentang Octopus vulgaris (Rochman et al., 2013; FAO, 2016).

Tujuan penelitian ini adalah untuk melihat morfometri pada gurita vulgaris (Octopus vulgaris) dari Perairan Desa Popisi, Pulau Banggai Laut, Sulawesi Tengah dengan parameter panjang mantel, panjang tentakel, berat, dan jenis kelamin.

\section{MATERI DAN METODE}

Proses observasi perairan dilakukan di Pulau Asasal, perairan Bekas Oyama, dan Batu Lobang, sedangkan pemancingan gurita hanya dilakukan di titik Batu Lobang (Gambar 1). Data primer yang digunakan dalam penelitian ini adalah data panjang mantel, panjang lengan, berat tubuh, dan jenis kelamin gurita yang diukur langsung di Desa Popisi. Dimensi gurita yang di ukur meliputi : Pengukuran panjang mantel dilakukan dari titik tengah mata hingga akhir posterior mantel. Panjang lengan diukur dari bawah mata hingga ke bagian ujung lengan terpanjang dalam kondisi utuh maupun terputus. Berat tubuh diukur dengan meletakkan seluruh bagian tubuh gurita basah di atas timbangan dan dilihat berat keseluruhan tubuh. Pengepul gurita di Desa Popisi membagi gurita menjadi 4 kategori berdasarkan kesepakatan antar pengepul dan suplier yaitu; Kategori $A=$ berat $\geq 1,4 \mathrm{~kg}$; Kategori $B=$ berat $0,9 \mathrm{~kg}-1,3 \mathrm{~kg}$; Kategori $C=$ berat $0,5 \mathrm{~kg}-0,9 \mathrm{~kg}$; Kategori $D=$ berat $\leq 0,4 \mathrm{~kg}$. Penentuan jenis kelamin dilihat dari lengan ke-3 sebelah kanan. Untuk penentuan lengan pertama kanan dan kiri, dilakukan dengan menunjuk dari pertengahan antara kedua mata dan ditarik kebawah sehingga lengan terbagi dua antara kanan dan kiri

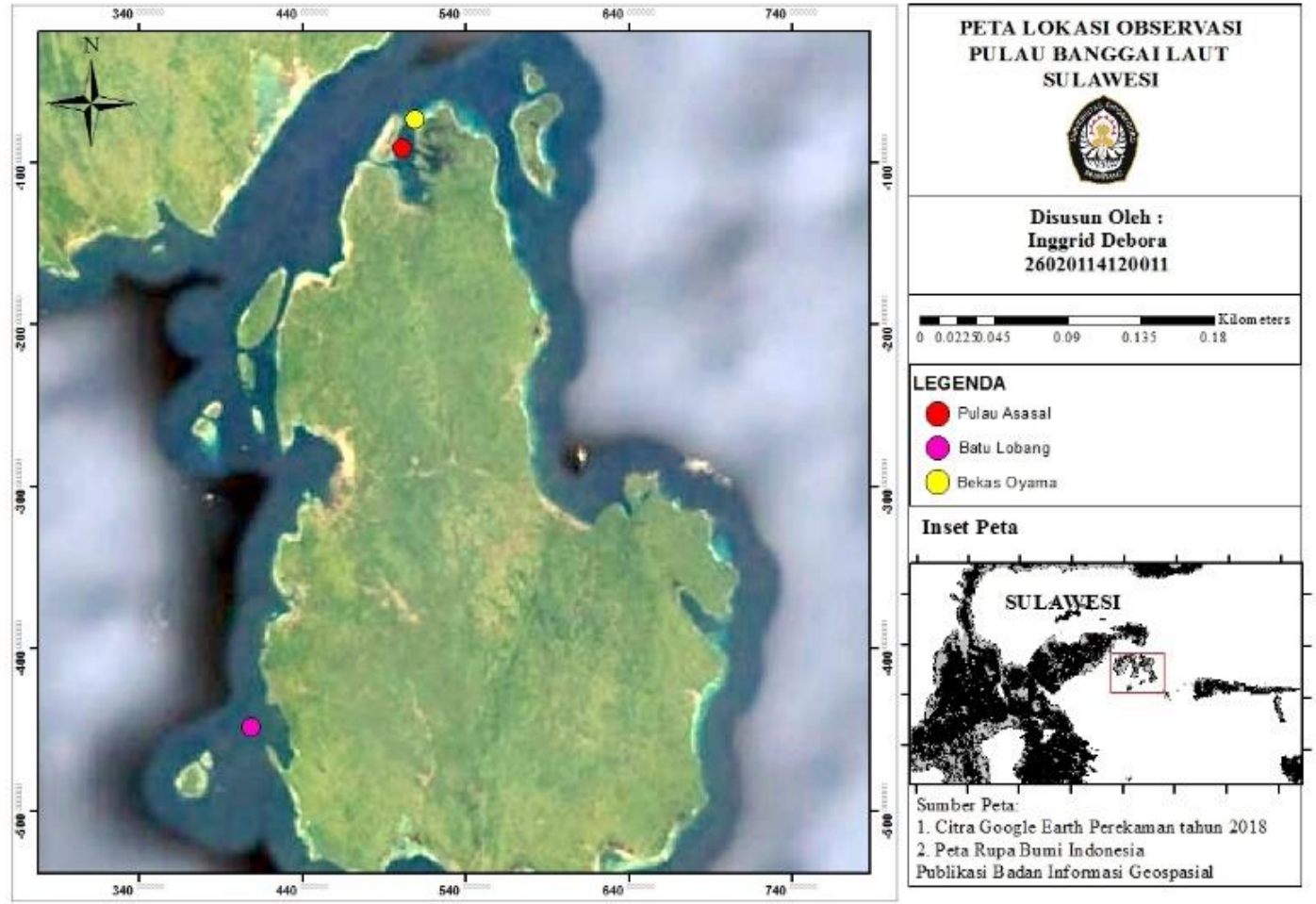

Gambar 1. Peta Lokasi Observasi. 


\section{HASIL DAN PEMBAHASAN}

Wilayah yang diamati merupakan perairan yang dekat dengan Desa Popisi dan sering dijadikan wilayah pemancingan gurita. Pulau Asasal didominansi dengan karang folios yang rapat, sedangkan pada perairan Bekas Oyama didominasi karang branching, dan karang pada Batu Lobang lebih beragam dengan didominasi karang meja, karang folios, karang massive. Kondisi tutupan karang tidak memiliki banyak rubble dan karang masih berwarna sehat (gambar 2). Dari pemancingan \pm 4 jam dengan nelayan didapat 8 ekor gurita dan 2 ekor gurita yang lepas. Setelah diukur gurita kategori $D$ ada 1 ekor, kategori $C$ ada 3 ekor, kategori B ada 2 ekor, kategori $A$ ada 2 ekor. Dari hasil wawancara dengan para nelayan gurita, gurita tidak terlalu banyak yang terpancing dan berukuran kecil pada kondisi tutupan karang yang terlalu rapat. Saat memancing gurita, nelayan memilih tutupan karang yang tidak memiliki terumbu karang yang sangat besar, namun jarang-jarang dan banyak lobang.

Alat pancing yang digunakan nelayan gurita popisi sangat ramah lingkungan dan konservatif. Saat memancing nelayan hanya menggunakan 2 umpan yaitu cipo dan manis-manis. Cipo dan manis-manis diikat pada tali nilon bening yang nantinya akan diulur saat memancing. Umpan cipo berbentuk seperti kerang dan kepiting (krustasea) yang berkelip, sedangkan manismanis merupakan umpan yang berbentuk seperti gurita. Cipo dibuat dari cangkang kerang yang di isi timah panas sekitar $1 \mathrm{~kg}$ dan ditempeli alumunium yang mengkilap seperti sendok. Sedangkan manis-manis dibuat dari kayu yang dibentuk seperti mantel gurita dan disekeliling bagian bawahnya diikat kain berumbai seperti lengan gurita. Menurut para nelayan umunya gurita yang tertangkap dengan umpan cipo adalah gurita jenis kelamin betina yang belum bertelur atau membuahi, sedangkan saat menggunakan umpan manis-manis biasanya gurita yang tertangkap adalah gurita jantan. Ukuran gurita yang paling berat umumnya terjadi selama musim gugur dan awal musim dingin dengan kemungkinan indikasi pertumbuhan dari populasi, sedangkan ukuran terkecil terjadi pada musim panas (Whitaker et al., 1991). Chapela et al. (2006), juga menyatakan Common octopus atau Octopus vulgaris pada musim panas berukuran 0,8 - 1,05 $\mathrm{kg}$ dan pada musim dingin sekitar 1,2-1,5 kg. Pada bulan Maret 2018, ukuran gurita jantan yang paling besar ada $3 \mathrm{~kg}$ dengan panjang mantel $17 \mathrm{~cm}$ dan panjang lengan $97 \mathrm{~cm}$. Untuk ukuran gurita betina yang paling besar ada ukuran 4,4 kg dengan panjang mantel $21 \mathrm{~cm}$ dan panjang lengan $115 \mathrm{~cm}$. Sedangkan pada bulan Juli 2017 ukuran gurita jantan yang paling besar ada $4 \mathrm{~kg}$ dengan panjang mantel $17 \mathrm{~cm}$. Dan untuk ukuran gurita betina yang paling besar ada ukuran $3 \mathrm{~kg}$ dengan panjang mantel $15 \mathrm{~cm}$.

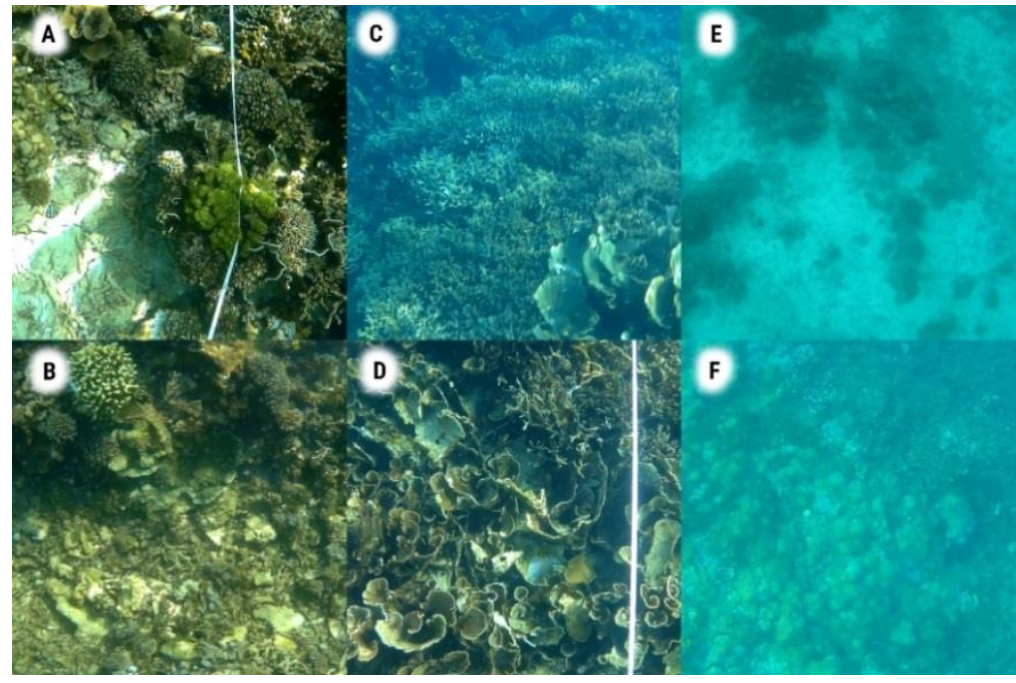

Gambar 2. Tutupan karang tempat gurita berada : A. Pantai Bekas Oyama $\pm 2 \mathrm{~m}$; B. Pantai Bekas Oyama $\pm 4 \mathrm{~m}$; C. Pantai Asasal $\pm 6 \mathrm{~m}$; D. Pantai Asasal $\pm 4 \mathrm{~m}$ ); E. salah satu tempat penangkapan gurita (Batu Lobang) pada kedalaman $\pm 15 \mathrm{~m}$; $\mathrm{F}$. salah satu tempat penangkapan gurita (Batu Lobang) pada kedalaman $\pm 13 \mathrm{~m}$ 


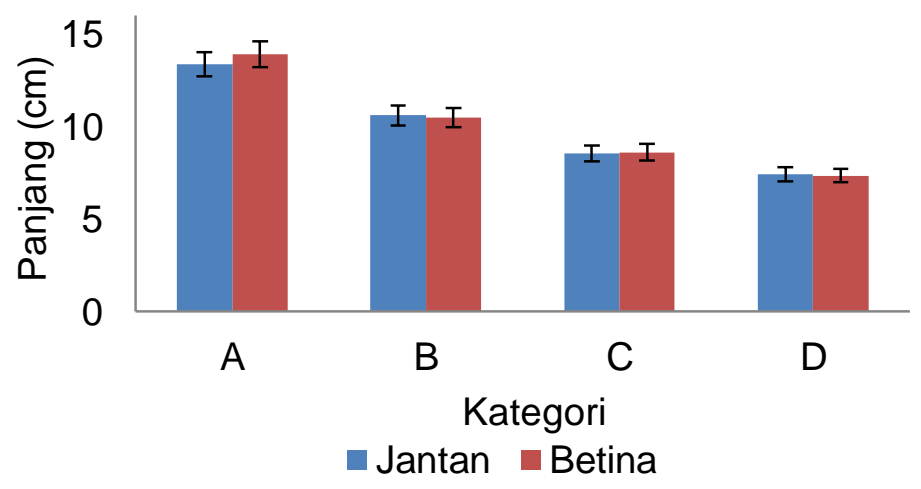

Gambar 3. Panjang mantel gurita dalam satuan centimeter yang dibagi menurut jenis kelamin jantan dan betina

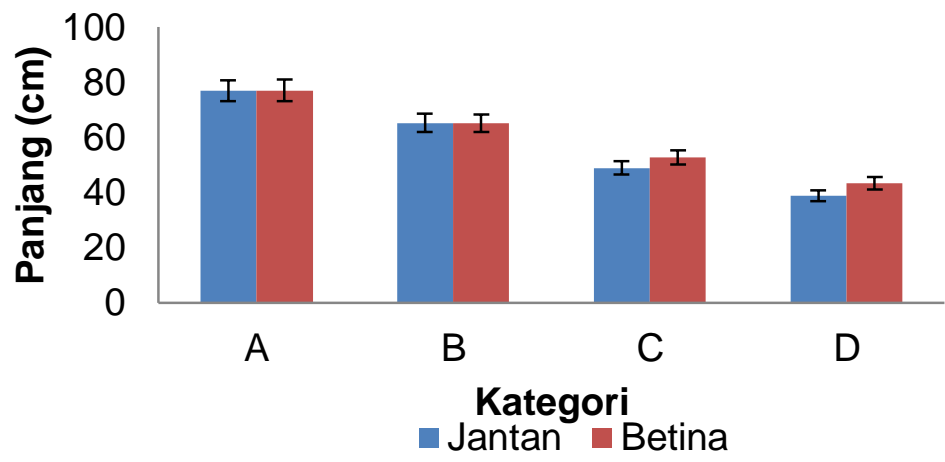

Gambar 4. Panjang lengan gurita dalam satuan centimeter yang dibagi menurut jenis kelamin jantan dan betina

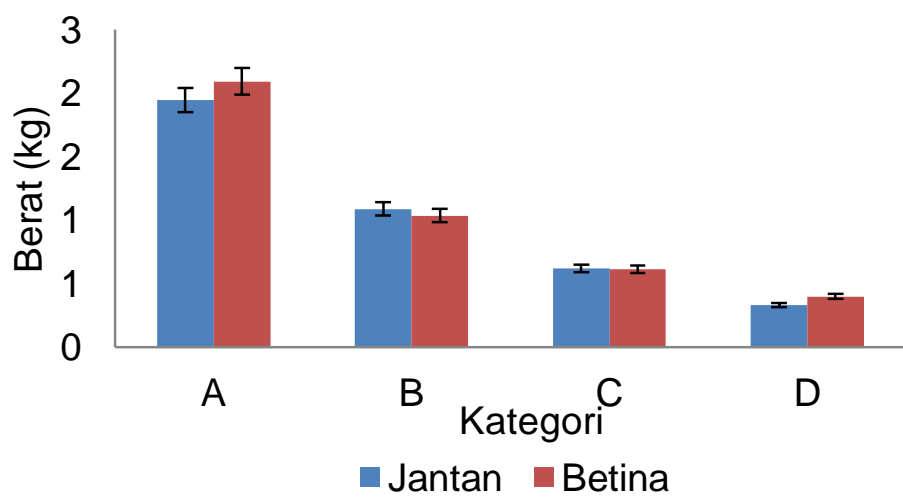

Gambar 5. Berat gurita dalam kilogram yang dibagi menurut jenis kelamin jantan dan betina

Hal ini mendukung pernyataan Whitaker et al. (1991) yang menyatakan hasil tangkapan paling besar terjadi pada bulan November-Maret dan Forsythe (1993) yang menyatakan penetasan telur pada musim yang berbeda mempengaruhi percepatan tumbuh gurita. Whitaker et al. (1991) juga menjelaskan kalau gurita betina yang ditangkap pada musim panas, tidak memiliki gonand yang besar. Hal ini ditunjukkan dengan ukuran mantel pada bulan Maret yang lebih besar dibanding bulan Juli, namun berat gurita rata-rata sama pada bulan Maret 2018 dan Juli 2017, tidak menunjukkan perbedaan yang pesat.

Perbedaan yang cukup terlihat terjadi pada jumlah jenis kelamin gurita yang tertangkap pada bulan Maret 2018 dan bulan Juli 2017. Secara dinamika dan biologi, Octopus vulgaris di Afrika Selatan ditemukan mirip dengan Octopus vulgaris di Barat Laut Pantai Afrika dan Laut Mediterian 
(Laut tengah) (Oosthuizen dan Smale, 2003). Jenis kelamin pada bulan Maret 2018 dominan betina yaitu pada musim gugur atau musim peralihan hujan-kemarau. Pada bulan Juli 2017 memasuki musim peralihan kemarau-hujan, hasil tangkapan gurita dominan berjenis kelamin jantan. Hal ini didukung oleh Leporati et al (2009) yang menyatakan pada penjualan gurita pada musim gugur di dominan oleh betina dan periode pemijahan meningkat.

Semakin panjang ukuran mantel, semakin tua si gurita. Bouth et al. (2011) membagi panjang mantel menjadi 4 kategori yaitu: extra-small (ES) berukuran $\pm 5 \mathrm{~cm}$ (kategori A); small (S) berukuran 5,1-8 cm (kategori B); medium (M) berukuran sekitar 8,1 - 10cm (kategori C); dan large (L) berukuran lebih dari $10 \mathrm{~cm}$ (kategori D). Ukuran extra-small (ES) dan small (S) merupakan ukuran juvenil (panjang mantel $<6,5 \mathrm{~cm}$ ) atau sub-adult (panjang mantel $<8 \mathrm{~cm}$ ). Data menyatakan panjang mantel pada bulan Maret 2018 untuk kategori $A$ adalah $13 \mathrm{~cm}$, kategori B adalah $10 \mathrm{~cm}$, kategori $C$ adalah $8 \mathrm{~cm}$, kategori $D$ adalah $7 \mathrm{~cm}$, dan pada bulan Juli 2018 untuk kategori $A$ adalah

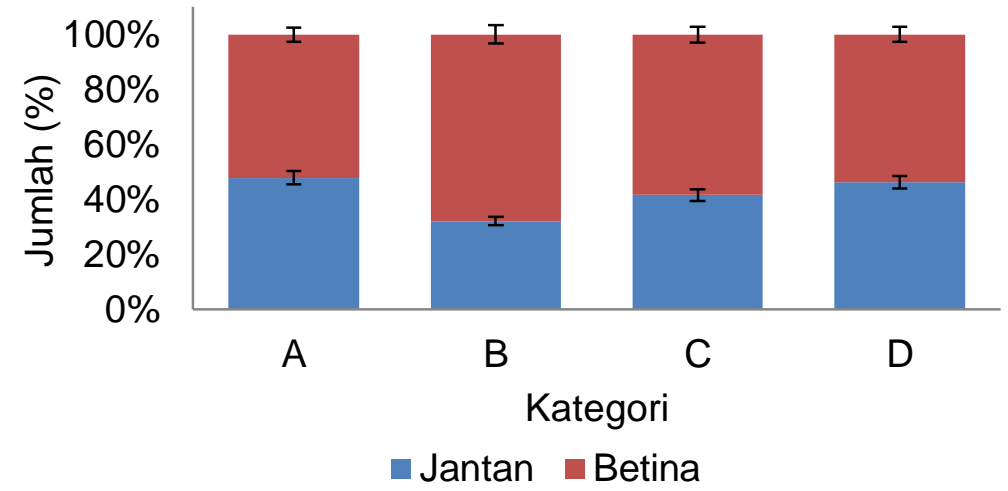

Gambar 6. Jenis kelamin gurita yang terhitung dan dibagi menurut jenis kelamin jantan dan betina

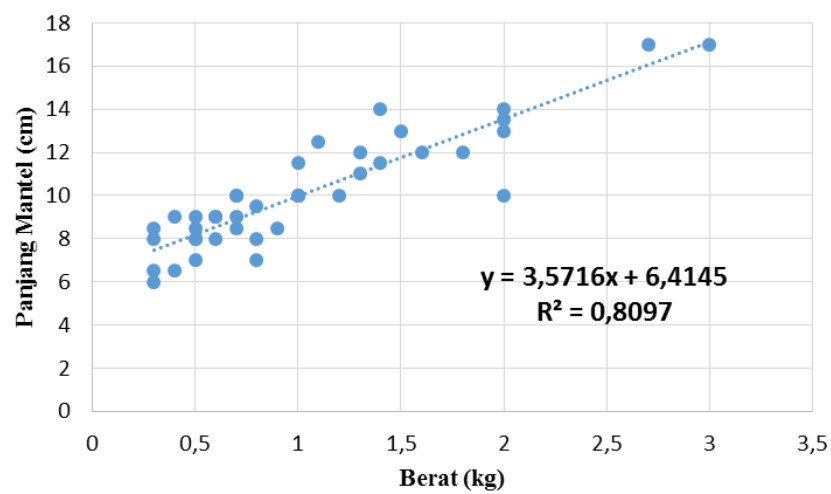

Gambar 7. Hubungan panjang mantel dengan berat tubuh gurita jantan dari perairan Desa Popisi

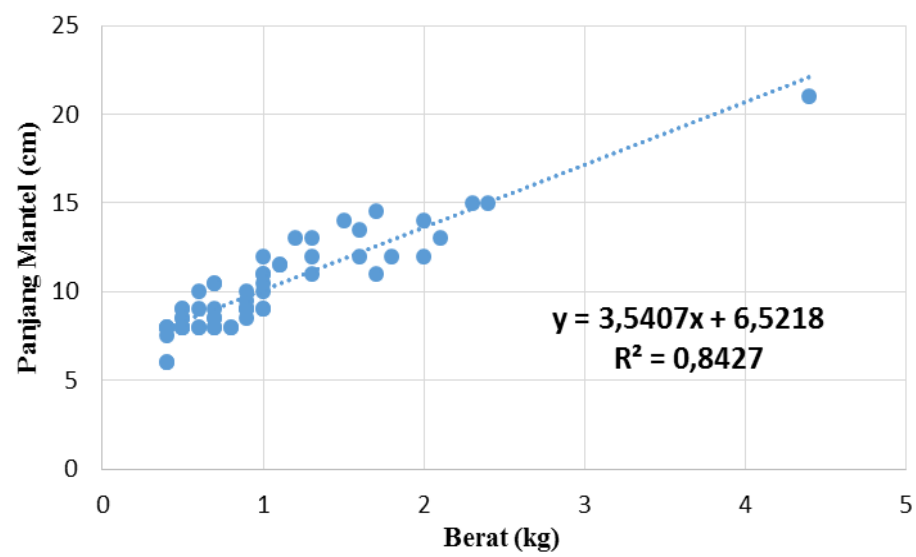

Gambar 8. Hubungan panjang mantel dengan berat tubuh gurita betina dari perairan Desa Popisi. 


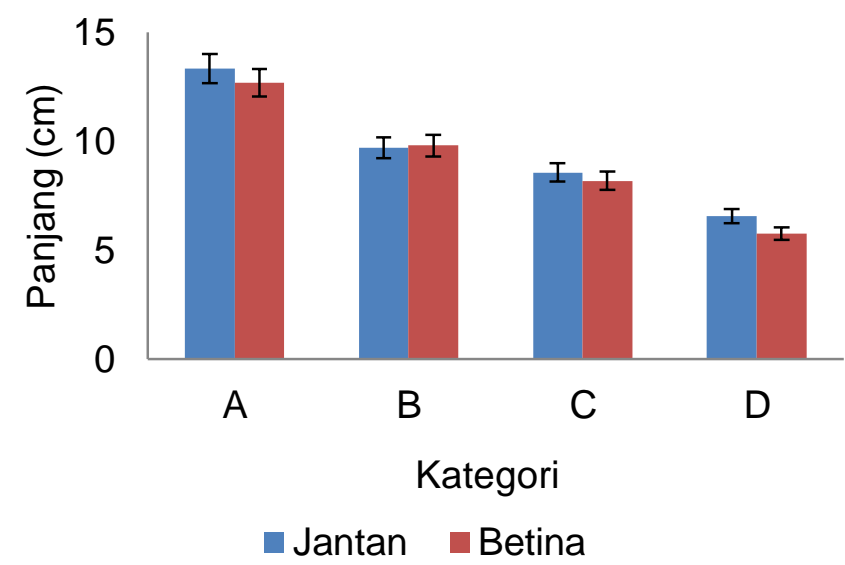

Gambar 9. Data sekunder panjang mantel gurita dalam satuan centimeter yang dibagi menurut jenis kelamin jantan dan betina.

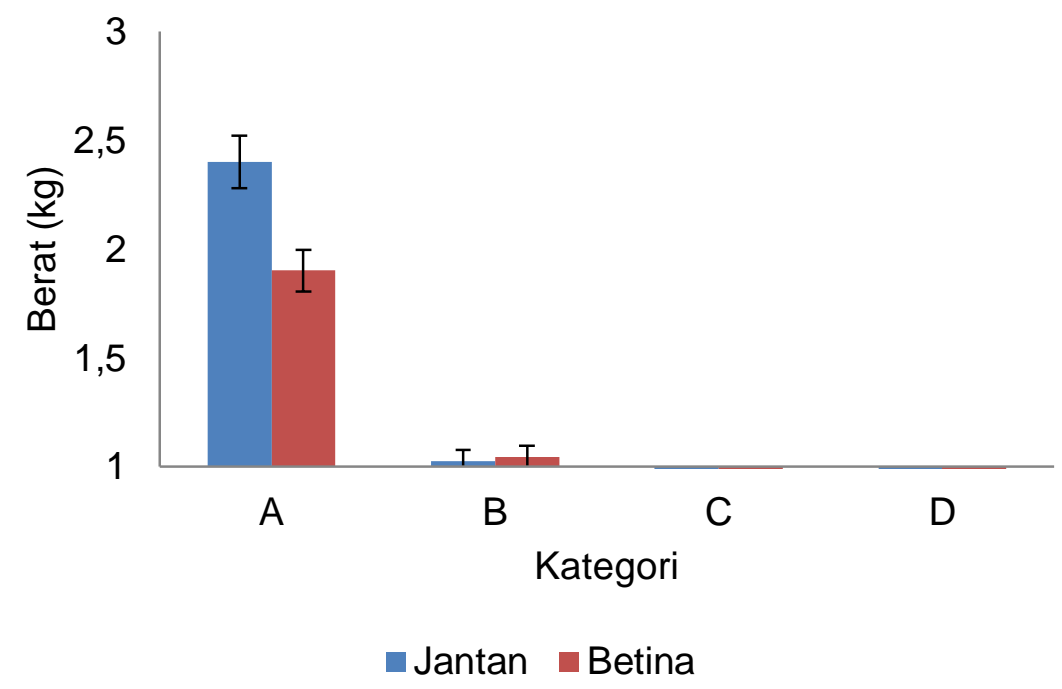

Gambar 10. Data sekunder berat gurita dalam satuan kilogram yang dibagi menurut jenis kelamin jantan dan betina

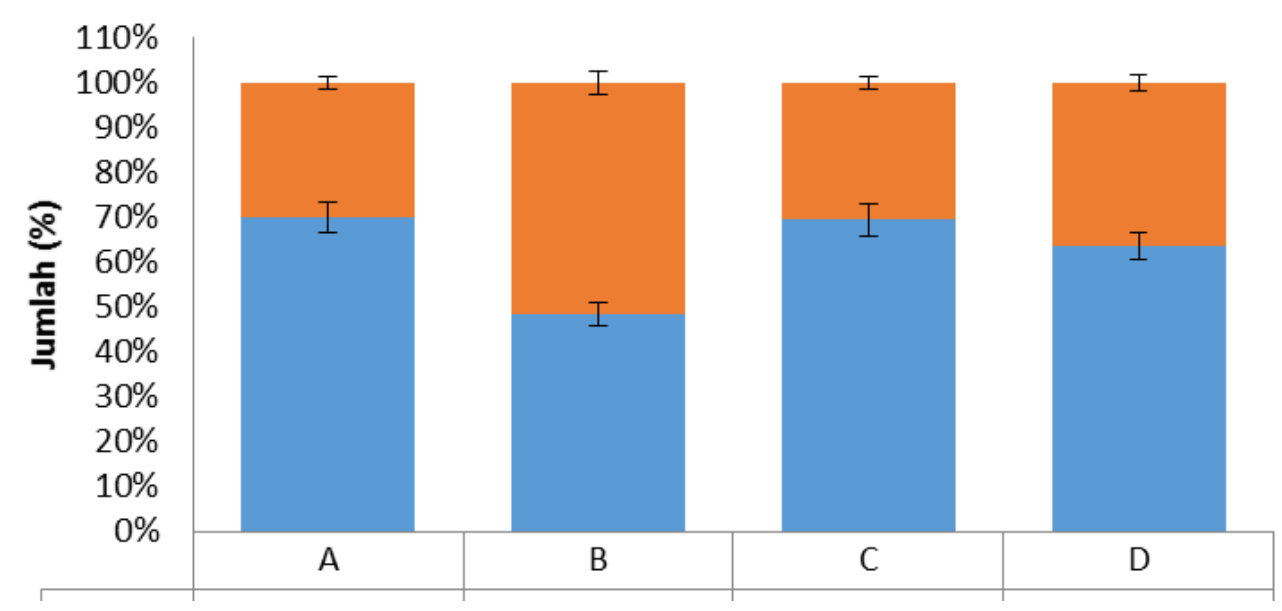

Gambar 11. Data sekunder jenis kelamin gurita dalam satuan kilogram yang dibagi menurut jenis kelamin jantan dan betina. 


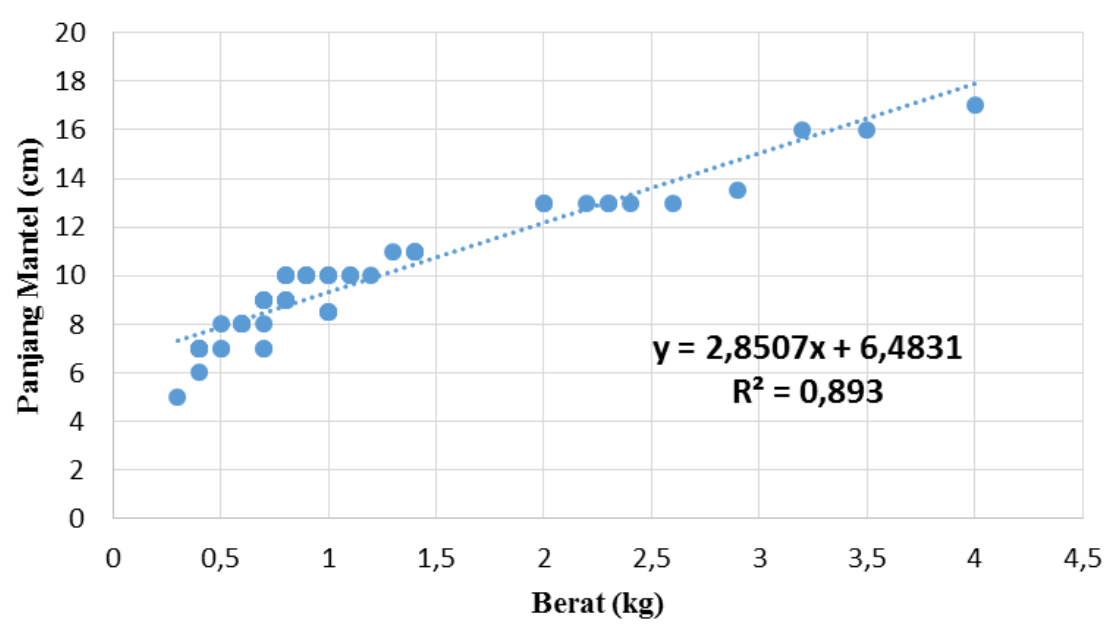

Gambar 12. Data sekunder hubungan panjang mantel dengan berat tubuh gurita jantan dari perairan Desa Popisi.

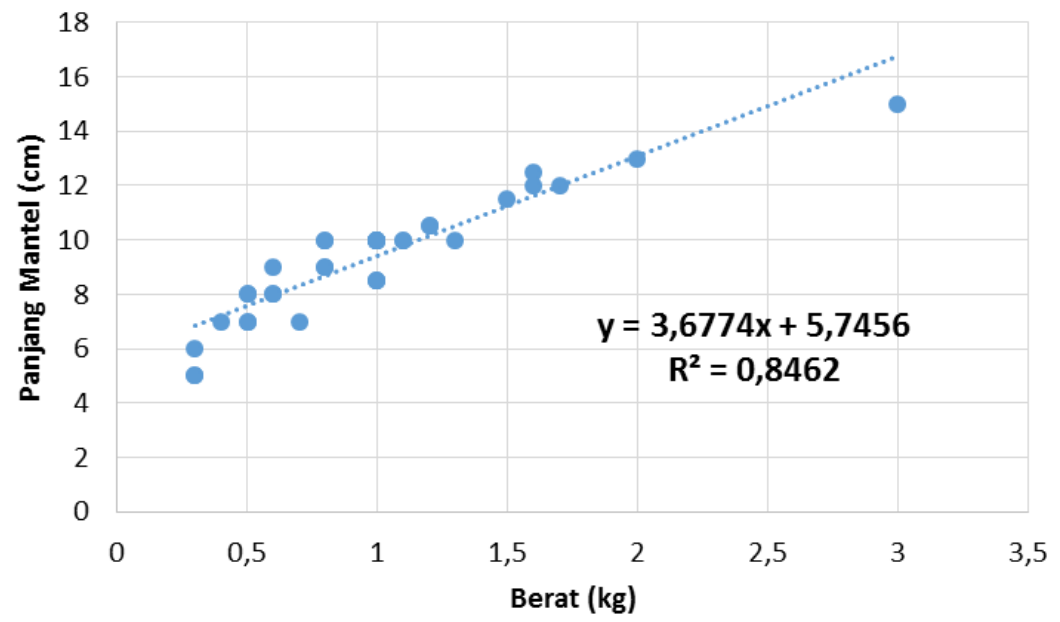

Gambar 13. Data sekunder hubungan panjang mantel dengan berat tubuh gurita betina dari perairan Desa Popisi.

$13 \mathrm{~cm}$, kategori $B$ adalah $9 \mathrm{~cm}$, kategori $C$ adalah $8 \mathrm{~cm}$, dan kategori D adalah $6 \mathrm{~cm}$. Rata-rata ukuran yang tertangkap oleh nelayan adalah ukuran $C$ yaitu sebesar $0,6 \mathrm{~kg}$. Carreira dan Goncalves (2009) menyatakan pada ukuran ini sudah layak untuk di ekspor. Pada kategori C ukuran mantel dan berat gurita sudah siap dibuahi, sehingga dianggap cukup dewasa.

Dari analisa hubungan panjang mantel dan berat gurita didapat nilai $b=3,5716$ untuk gurita jantan dan nilai $b=3,5407$ untuk gurita betina, menunjukkan pertumbuhan allometrik positif yaitu pertumbuhan panjang mantel lebih lambat dibanding pertumbuhan berat tubuh. Data sekunder yang didapat dari para pengepul menunjukkan nilai $b=2,8507$ untuk gurita jantan dan nilai $b=3,6774$ untuk gurita betina. Gurita betina pada bulan Juli 2017 menunjukkan pertumbuhan allometrik positif. Namun pada gurita jantan bulan Juli 2017 menunjukkan pertumbuhan allometrik negatif, dimana pertumbuhan panjang mantel lebih cepat dibandingkan pertumbuhan berat. Pada gurita betina yang memijah pada musim panas (kemarau) lebih cepat tumbuh dibanding penetasan pada musim dingin (penghujan), dan akan mencapai ukuran besar pada usia muda (Forsythe, 1993). Namun hal ini tidak dapat dibandingkan dengan pengaruh umur karena panjang yang digunakan hanya panjang mantel (bukan panjang total). Panjang lengan gurita pada perairan yang hangat lebih cepat panjang dibanding pertambahan berat gurita (Forsythe, 1993). Pada gurita jantan semakin panjang lengan, semakin aman gurita jantan melakukan perkawinan (Agus dan Herri, 1997; Hanlon dan Messenger, 2003). 


\section{KESIMPULAN}

Gurita dari Desa Popisi pada bulan Maret 2018 dalam ukuran yang baik untuk di jual dan di ekspor, yaitu $87 \%$ gurita hasil tangkapan berukuran besar dengan kategori $\mathrm{A}, \mathrm{B}$, dan $\mathrm{C}$. Perairan Desa Popisi, Pulau Banggai Laut, Sulawesi Tengah pada bulan Maret 2018 tergolong masih aman dari eksploitasi dengan gurita kategori $\mathrm{A}$ berjumlah $23 \%$, kategori $\mathrm{B}$ berjumlah $28 \%$, kategori $\mathrm{C}$ berjumlah $36 \%$, kategori $\mathrm{D}$ berjumlah $13 \%$. Morfometri panjang mantel, berat dan jumlah jenis kelamin gurita betina dominan pada bulan Maret 2018 dan gurita jantan pada Juli 2017. Panjang mantel dan lengan bertambah dengan bertambahnya berat gurita. Pulau Banggai Laut menjadi salah satu wilayah yang masih baik dalam penangkapan gurita karena penangkapan yang konservatif.

\section{DAFTAR PUSTAKA}

Bouth, H.F., Leite, T.S., de Lima, F.D. \& Oliveira, J.E.L., 2011. Atol das Rocas: an oasis for Octopus insularis juveniles (Cephalopoda: Octopodidae). Zoologia, 28(1):45-52.

Budiyanto, A. \& Sugiarto, H., 1997. Catatan Mengenai Si Tangan Delapan (Gurita/Octopus sp). Jurnal Oseana, 22(2):25-33.

Carreira, G.P. \& Gonçalves, J.M., 2009. Catching Octopus vulgaris With Traps In The Azores: First Trials Employing Japanese Baited Pots In The Atlantic. Journal marine biodiversity records 2(c114): 1-4. DOI:10.1017/S1755267209000499

Chapela, A., González, Á.F., Dawe, E.G., Rocha, F.J. \& Guerra, Á., 2006. Growth of Common Octopus (Octopus vulgaris) in Cages Suspended from Rafts. Scientia Marina. 70(1):121-129

FAO. 2016. Cephalopods of the World. Species Catalogue for Fishery Purposes 4(3). ISSN 10208682.

Forsythe, R.W., 1993. A Working Hypothesis of How Seasonal Temperature Change May Impact The Eld Growth of Young Cephalopods. In Recent Advances in Sheries Biology. Tokyo: Tokai University Press. Hal: 133-143.

Hanlon, R.T. and Messenger, J.B., 2018. Cephalopod behaviour. Cambridge University Press.

Hoving H.J.T. \& Haddock S.H.D. 2016. The Giant Deep-Sea Octopus Haliphron atlanticus Forages On Gelatinous Fauna. Scientific Repots 7:44952 DOI: 10.1038/srep44952.

Kementrian Kelautan dan Perikanan. 2018. Produktivitas perikanan Indonesia. Forum Merdeka Barat 9, Kementrian Komunikasi dan Informatika.

Leporati, S.C., Ziegler, P.E. and Semmens, J.M., 2009. Assessing the stock status of holobenthic octopus fisheries: is catch per unit effort sufficient?. ICES Journal of Marine Science, 66(3):478-487.

McConnell, K.M. \& Scott, K., 2010. Prey Species Preference and Specialized Feeding Behavior in the Maditerranean Octopus vulgaris.

Nande, M., Presa, P., Roura, Á., Andrews, P.L. \& Pérez, M., 2017. Prey capture, ingestion, and digestion dynamics of Octopus vulgaris paralarvae fed live zooplankton. Frontiers in physiology, 8:573.

Oosthuizen, A. \& Smale, M.J., 2003. Population biology of Octopus vulgaris on the temperate south-eastern coast of South Africa. Journal of the Marine Biological Association of the United Kingdom, 83(3):535-541.

Rochman, N. \& Afiati, N., 2013. Studi Morfometri Dan Faktor Kondisi Sotong (Sepiella Inermis: Orbigny, 1848) Yang Didaratkan Di Ppi Tambaklorok, Semarang. Management of Aquatic Resources Journal, 2(4):91-99.

Sarif, F.S., Pringgenies, D., Hartoko, A \& Sibero, M.S., 2018. Kemunculan Paper Nautilus di Perairan Teluk Tomini Kabupaten Parigi Moutong, Provinsi Sulawesi Tengah. In Prosiding Seminar Nasional Kelautan dan Perikanan III (pp. 28-32). Universitas Trunujoyo.

Whitaker, J.D., DeLancey, L.B. \& Jenkins, J.E., 1991. Aspects of Biology and Fishery Potential for Octopus vulgaris off the Coast of South Carolina. Bulletin of Marine Science, 49(1-2):482-493. 